\title{
Assessment of the potential genotoxic and proapoptotic impact of selected cyanotoxins on fish leukocytes
}

\author{
ANNA SIEROSŁAWSKA, ANNA RYMUSZKA
}

Department of Physiology and Ecotoxicology, The John Paul II Catholic University of Lublin, Poland

\begin{abstract}
Cyanotoxins, toxic secondary metabolites of cyanobacteria, are able to induce a wide range of negative health effects in the intoxicated organisms. Except for their well-described hepatotoxic or neurotoxic activities, cyanotoxins are also considered to possess other properties, such as immunotoxicity or genotoxicity. The aim of the work was to study the potential cytotoxic/genotoxic impact of selected cyanotoxins (microcystin-LR, cylindrospermopsin and anatoxin-a) on common carp leukocytes. The cells were exposed to the toxins at $0.5 \mu \mathrm{g} / \mathrm{ml}$ for $18 \mathrm{~h}$. DNA damage in the cells was studied with the use of the alkaline version of the comet assay detecting single-and double-strand DNA breaks. Apoptotic cells were identified on the basis of phosphatidylserine translocation in the plasma membrane and the cell viability was checked by the propidium iodide staining. The most substantial changes were detected in the leukocytes exposed to microcystin-LR, in which a high level of DNA damage was observed, but there was also a high number of apoptotic cells. No such effects were observed after cell exposure to anatoxin-a. Cylindrospermopsin did not intensify apoptosis or necrosis, however some increase in DNA damage was detected.
\end{abstract}

Key words: microcystin-LR, cylindrospermopsin, anatoxin-A, carp, genotoxicity, apoptosis, necrosis.

(Centr Eur J Immunol 2013; 38 (2): 190-195)

\section{Introduction}

Cyanotoxins, which are mostly secondary metabolites of cyanobacteria, are responsible for a wide range of negative health effects in the intoxicated aquatic and terrestrial organisms [1, 2]. During decay of cyanobacterial water blooms, the content of the bloom-forming cells is released into the water and cyanobacterial-derived toxic compounds may reach high concentrations, posing a threat to the organisms using such contaminated water. Except for welldescribed negative outcomes of intoxication with cyanotoxins, such as hepatotoxicity or neurotoxicity [3], there is an increasing number of reports indicating also other possible effects of the toxins, of not fully understood mechanisms, such as immunotoxicity or genotoxicity [4-6]. Microcystins (MCs), the most frequently detected cyanotoxins, are transported through plasmatic membranes by the multispecific organic anion transporting polypeptide superfamily (rodent
Oatps, human OATPs), mainly expressed on hepatocytes [7], which makes the liver the target for these toxins. The main mode of action of MCs inside the cell is inhibition of serine/threonine phosphatases 1 and 2A (PP1 and PP2A). In addition to such effects as hyperphosphorylation of the cytoskeleton, disorders of vital cellular processes and, in consequence, the hepatocyte disruption [8], MCs are also able to induce DNA damage in these cells [8-10]. Moreover, it has been found that MCs may exert genotoxic changes not only in the liver, but also in such cells as fibroblasts, kidney cells [11] or in human lymphocytes [12, 13].

The other potent toxin produced by cyanobacteria is cylindrospermopsin (CYN). Its main mechanism of the toxic activity is irreversible inhibition of protein synthesis at the stage of elongation [14]. There is also another way in which CYN affects the cells and this manner needs previous toxin transformation by P450 enzymes [14]. Similarly to MCs, the main target for $\mathrm{CYN}$ is the liver. The studies

Correspondence: dr Anna Sierosławska, Department of Physiology and Ecotoxicology, Institute of Biotechnology, The John Paul II Catholic University of Lublin, Konstantynów 1 I, 20-708, Lublin, Poland, tel. + 488147594 53, e-mail: ansie@kul.lublin.pl 
on CYN genotoxic potential revealed that the toxin is also responsible for DNA damage in hepatocytes [15]. Recently, the toxin-induced formation of DNA single-strand breaks, increase in the frequency of micronuclei and nuclear buds in human peripheral blood lymphocytes exposed to CYN were reported [16].

On the other hand, there is nearly no information on possible genotoxic properties of the another frequently detected cyanotoxin, anatoxin-a (Antx-a). That toxin is a small alkaloid of strong neurotoxic activity. Only one study was found in the literature, which assessed toxin genotoxicity with the use of the umuC assay, in which the induction and expression of the umuC - lacZ reporter gene in bacteria Salmonella typhimurium was examined [17].

Fish, due to their habitat, are especially subjected to intoxication with cyanotoxins. There are only a few studies on the potential genotoxicity of cyanobacterial products on these organisms. Available data indicate that cyanotoxins may induce changes in nuclei of kidney cells, erythrocytes or embryos of different fish species [18-20]. Moreover, disruption of some vital functions of immune cells of fish was reported [21]. To the authors' knowledge, there are no data on genotoxic effects of cyanotoxins on common carp (Cyprinus carpio L.) blood leukocytes.

The aim of the present work was to study the potential cytotoxic/genotoxic impact of three cyanotoxins - MC-LR, the most toxic variant among all MCs, CYN and Antx-a on common carp leukocytes. The comet assay (single cell gel electrophoresis, SCGE) was chosen because of its sensitivity and possibility to detect a wide range of DNA damage, such as single/double-strand DNA breaks, alkali labile sites (apurinic/apyrimidinic sites), DNA cross-links and base/base-pair damage in the cells. Additionally, to elucidate if the potential positive effects in the comet assay came from the cyanotoxin-induced genotoxic damage or they were the effects of nuclear fragmentation being a part of apoptosis, the percentage of apoptotic/necrotic cells in the leukocyte cultures was estimated.

\section{Material and methods Cyanotoxins}

The following cyanotoxins in pure form were used: MCLR and CYN purchased from Alexis (Switzerland) and Antxa as a fumarate salt obtained from Tocris Bioscience (USA).

\section{Experimental setup}

In the study, the principles of laboratory animal care and the national laws (Opinion and Approval of Local Committee of Ethics No. 3/2009) were followed. Five common carps of either sex and mean body weight of $320 \pm 35 \mathrm{~g}$ were obtained from the local breeding farm. Blood of fish was sampled from vena caudalis with heparin at $50 \mathrm{IU} / \mathrm{mL}$ and diluted with a Dulbecco's Phosphate Buffered Saline (DPBS,
BI, Israel). Leukocytes were isolated by blood centrifugation on Gradisol G (1.119 g/ml, Aqua-Med, Poland). Obtained cells (containing about $80 \%$ of lymphocytes) at a concentration of $5 \times 10^{6} \mathrm{cell} / \mathrm{ml}$ were suspended in complete RPMI 1640 medium (BI, Israel) containing 5\% of heatinactivated autological serum and $1 \%$ of penicillin/streptomycin solution. The cell suspension was dispensed to the 24-well microtitre plates in the aliquots of $1 \mathrm{ml}$ per well with an addition of the appropriate toxin (MC-LR, CYN or Antxa) at $0.5 \mu \mathrm{g} / \mathrm{ml}$ and incubated at $24^{\circ} \mathrm{C}, 0.5 \% \mathrm{CO}_{2}$, in the dark. After $18 \mathrm{~h}$, the cells were harvested for further research.

\section{DNA damage detection}

The alkaline version of the comet assay was performed with the use of the CometAssay kit (Trevigen) to detect DNA damage in the cells after their exposure to the cyanotoxins. The producer's protocol was followed. Shortly, leukocytes at $1 \times 10^{5}$ cell $/ \mathrm{ml}$ were combined with low melting point agarose (LMA) and placed onto the slides. For each toxin, two slides were prepared. After $30 \mathrm{~min}$ incubation at $4^{\circ} \mathrm{C}$ in the dark, the cells were lysed with Lysis Solution for $60 \mathrm{~min}$ at $4^{\circ} \mathrm{C}$. Then, the slides were immersed in Alkaline Unwinding Solution $(\mathrm{pH}>13)$ for $60 \mathrm{~min}$. Electrophoresis was carried out with chilled Alkaline Electrophoresis Solution (200 mM NaOH, 1 mM EDTA, $\mathrm{pH}>13$ ) at $1 \mathrm{~V} / \mathrm{cm}, 300 \mathrm{~mA}$, for $30 \mathrm{~min}$ at $4^{\circ} \mathrm{C}$ in the dark. The slides were immersed twice in $\mathrm{dH} 2 \mathrm{O}$ and for $5 \mathrm{~min}$ in $70 \%$ ethanol. After drying, the slides were stained with SYBR Green I dye and viewed with a Nikon Eclipse T $i$ inverted fluorescence microscope. The comet images were analyzed with CASP ver. 1.2.3b1 software to determine the percentage of DNA within the comet tail (at least 100 nuclei per treatment and per control).

\section{Apoptosis/necrosis detection}

After the end of the incubation period, the cells were washed in DPBS and adjusted to the concentration of $5 \times$ $\times 10^{6}$ cell $/ \mathrm{ml}$. Then, leukocytes were stained with annexin $\mathrm{V}$ conjugated to fluorescein (An V FITC) and propidium iodide (PI) with the use of the Annexin-V-FLUOS Staining kit (Roche Diagnostic, Germany) for $15 \mathrm{~min}$, according to the producer's protocol. Stained cells were analyzed with the fluorescence microscope. Approximately 100 cells for each toxin treatment were counted. The cells with green fluorescence (An V FITC positive) were treated as apoptotic, while the cells with red fluorescence (PI positive) or with red and green fluorescence (An V FITC and PI positive) were treated as necrotic. The results are presented as a percentage of apoptotic/necrotic cells in the cultures exposed to the toxins in relation to the control cells.

\section{Statistical analysis}

Statistical analyses were performed by nonparametric Mann-Whitney $U$ test with Statistica 8.0 software from Stat- 


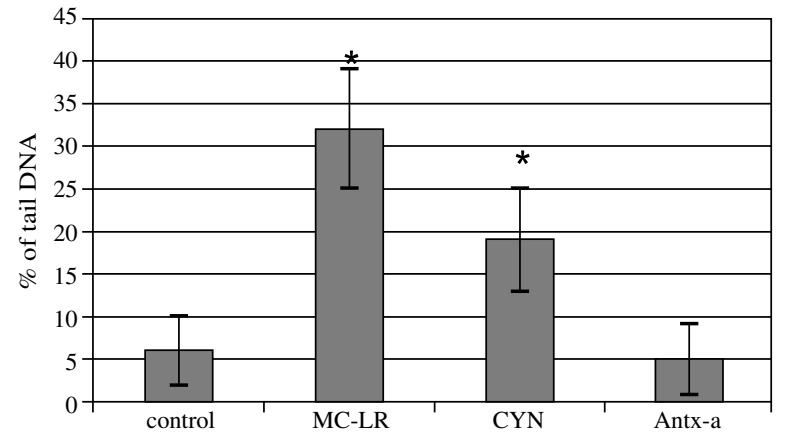

Fig. 1. DNA damage (expressed as a percent of DNA in the comet tail) in common carp blood leukocytes exposed to cyanotoxins (MC-LR, CYN or Antx-a) at $0.5 \mu \mathrm{g} / \mathrm{ml}$ for $18 \mathrm{~h}$ (mean $\pm \mathrm{SD}, * p<0.05)$

Soft Inc. (Tulsa, OK, USA). $P$ values $<0.05$ were considered as statistically significant.

\section{Results}

\section{DNA damage}

Percentage of DNA in the tail of the exposed cells was significantly higher $(p<0.05)$ comparing to the control cells in two cases (Fig. 1). The most substantial DNA damage was observed in the cells exposed to MC-LR (Fig. 2B). The cells treated with CYN were affected to a lesser extent, however still to a significant degree (Fig. 2C). On the contrary, no signs of increased DNA fragmentation were observed in the cells incubated in the presence of Antx-a, and generally the images taken from the control cell nuclei did not differ essentially from those of Antx-a treated cell (Fig. 2A and 2D).

\section{Apoptosis/necrosis}

According to the phosphatidylserine dislocation in the plasma membrane, a high number of apoptotic cells was found after cell treatment with MC-LR. In the other cell populations, i.e. the CYN-treated and the Antx-a-treated, apoptotic cells were not substantially more frequent than in the control population. Moreover, there were low rates of necrosis in all studied cell groups, estimated on the basis of the cell membrane integrity (Fig. 3).

\section{Discussion}

Leukocytes, the cells of the immune system, play a crucial role in sustaining organism homeostasis. Thus, it is important to recognize the possible factors influencing their viability and normal functioning. It is known that some toxic substances, except for their direct effects on the target organ/tissue, are also able to disrupt various immune reac-
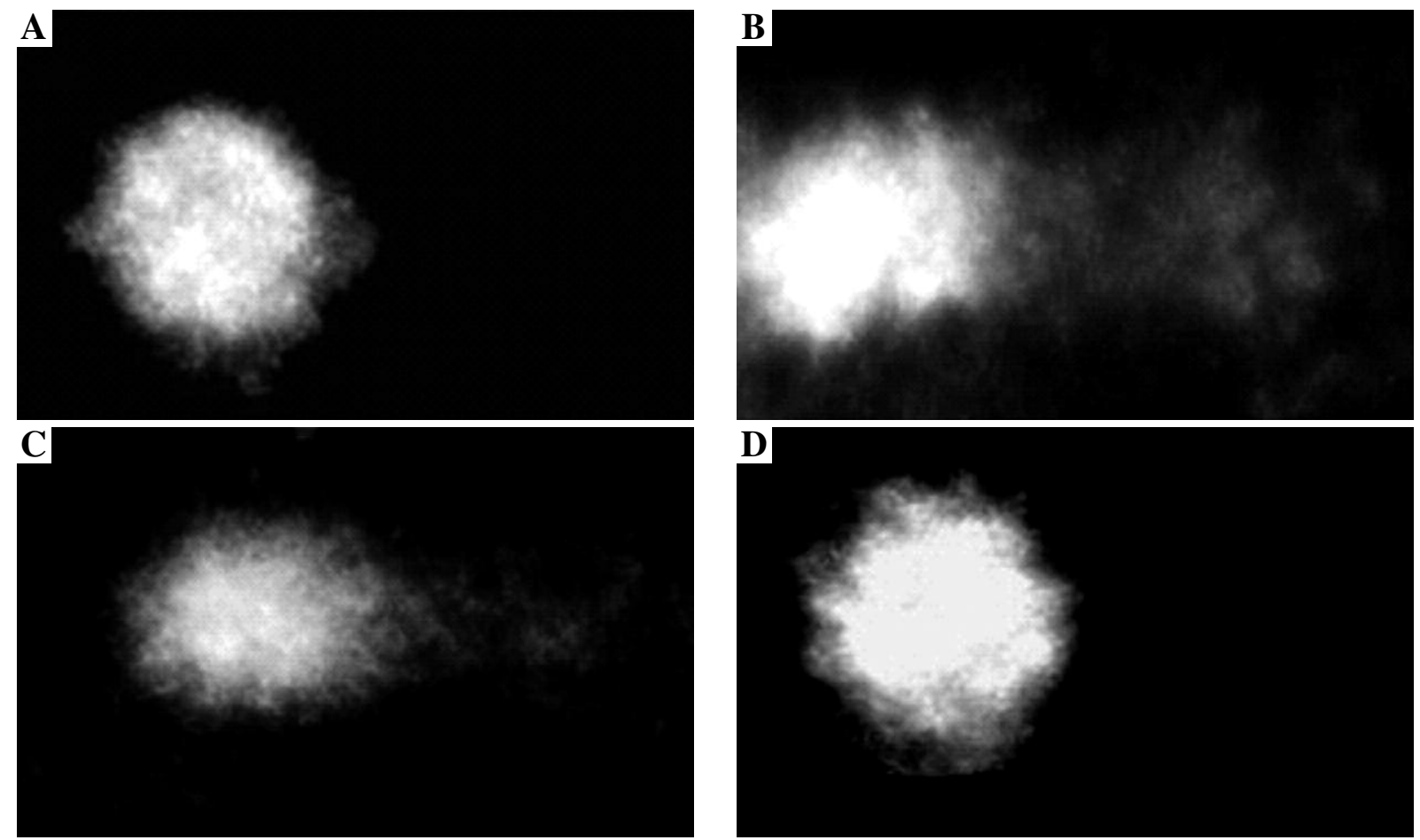

Fig. 2. The examples of comet images obtained after cell treatment with the toxins: A) control cell, B) cell treated with MCLR, C) cell treated with CYN, D) cell treated with Antx-a 
tions. In these cases, in a hazard assessment, also changed or reduced abilities to fight pathogenic microorganisms or malignant cells should be taken under consideration.

The present study was conducted to examine whether well-known cyanotoxins, hepatotoxins MC-LR and CYN, as well as neurotoxin Antx-a, are able to exert cytotoxic/genotoxic effects on carp leukocytes.

The most evident results were obtained after the cell treatment with MC-LR. Observed high amounts of DNA in the comet tails after electrophoresis of the lysed cells indicated the presence of numerous DNA breaks. As the main components of the cell population were lymphocytes, the observed effects refer mainly to that kind of fish leukocytes.

The toxin-induced nuclear damage was also reported in many hepatocyte-based experiments, even at much lower concentrations than used in the present study [22-24], as well as in non-hepatocytic mammalian cells [25]. Human lymphocytes were relatively widely studied in that regard [12, 13]. In general, it is believed that MC-LR is a potent reactive oxygen species (ROS) inducer $[8,26]$. In consequence, oxidative DNA lesions may be expected. Indeed, formation of 8-oxo-7,8-dihydro-2'-deoxyguanosine (8-oxo-dG), one of the most abundant products of DNA oxidation, has been found in the cells exposed to MC-LR [9, 27]. Moreover, the toxin inhibits enzymes involved in the repair of DNA damage [28]. On the other hand, Zegura et al. [25] did not observe any substantial DNA strand break induction in the NCNC human B-lymphoblastoid cell line exposed to the toxin at concentrations up to $10 \mu \mathrm{g} / \mathrm{ml}$ for $2-16 \mathrm{~h}$. It indicates differences among different cells as the susceptibility of the cells from different tissues may vary and some cell lines may possess other susceptibility than primary cells.

There are not many data from studies on fish cells in this respect. Recently, Wu et al. [20] has found that a cyanobacterial extract containing MC-LR was able to induce DNA and chromosome damage detected by the micronucleus assay and the SCGE assay in carp erythrocytes and kidney cells after a few-day in vivo exposure. Proapoptotic and cytotoxic influence of MC-LR on carp leukocytes, manifested as the increase of LDH leakage, increased number of apoptotic and necrotic cells, changes in intracellular GSH levels and affected phagocytic activity, was also observed by Rymuszka [21].

When assessing genotoxic effects with the comet assay, we have to consider some demands. The low viability of the studied cell population, as well as the cells during $S$ phase, may give false positive results [29]. In the present study, there were not many necrotic cells, but we saw a high rate of apoptotic cells. During apoptosis, caspase-dependent degradation of nuclear DNA occurs [30]. It gives an increased amount of DNA fragments of a specified length, while the comet assay does not provide exact information on the size of fragments in the comet tail. That is why the assay alone may not testify to direct genotoxicity of the studied agent [29]. The method of apoptotic cell identifi-

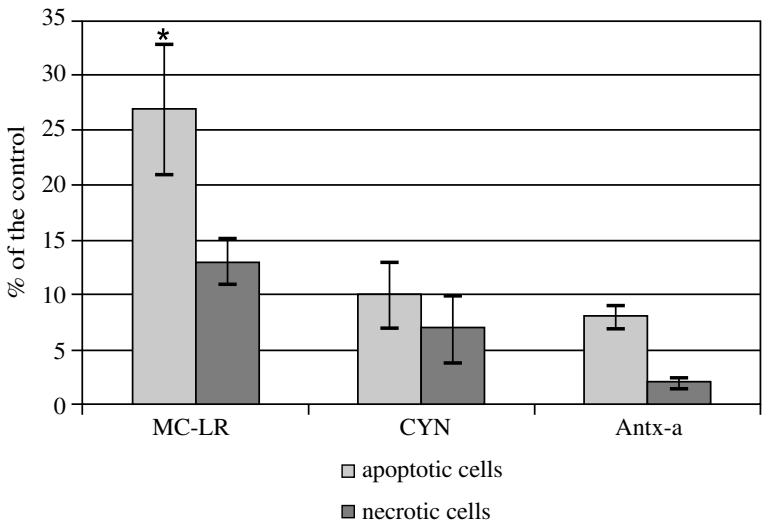

Fig. 3. Percentage increase of apoptotic (An V FITC positive) and necrotic (PI positive or An V FITC and PI positive) cell numbers in relation to the control level, after common carp blood leukocytes exposure to cyanotoxins (MC-LR, CYN or Antx-a) at $0.5 \mu \mathrm{g} / \mathrm{ml}$ for $18 \mathrm{~h}($ mean $\pm \mathrm{SD}, * P<0.05)$

cation used here is based on detection of translocations of phosphatidylserine from the inner layer of the cell membrane to the outer one, which is a hallmark of early stages of apoptosis [31]. Whereas major DNA fragmentation is generally a late event in apoptosis [32], and late apoptotic cells stain with both An V FITC and PI, we think that a high rate of DNA in comet tails after MC-LR treatment is at least partially a sign of direct genotoxic disruption.

On the contrary, in the CYN-treated cell population the number of apoptotic cells was low. Nevertheless, an increased amount of DNA strand breaks was observed, indicating genotoxic potency of the toxin. Most studies concerning the cytotoxic/genotoxic influence of CYN was conducted with liver cells or hepatoma cell lines as CYN is known to be a hepatotoxin. These studies confirmed that the toxin is able to induce genotoxic damage, such as DNA strand breaks, the increase in the micronuclei number, nuclear buds and nuclear bridges [15, 33-35]. Similar effects were also observed in other metabolically active cells, e.g. kidney or ileum cells $[34,36]$. It has been also found that inhibition of P450 enzymes abolished the genotoxicity induced by that toxin, which proves that CYN metabolites are mainly responsible for DNA damage [15]. Recently, Zegura et al. [16] has described the genotoxic effects of CYN on human lymphocytes, in which increase in the amount of DNA strand breaks, the induction of micronuclei and nuclear buds was observed after cell exposure to the toxin at a concentration of $0.5 \mu \mathrm{g} / \mathrm{ml}$ and below. In the present study, a similar increase in DNA fragments in comet tails was observed. On the other hand, Liebel et al. [37] did not detect any DNA damage in hepatocytes from Prochilodus lineatus exposed to the toxin at concentrations up to $10 \mu \mathrm{g} / \mathrm{ml}$ for $72 \mathrm{~h}$. In that study, however, increased reactive 
oxygen/nitrogen species levels and lipid peroxidation were found. In tilapia (Oreochromis niloticus) acutely exposed in vivo on CYN, increase in NADPH oxidase activity, a biomarker of reactive oxygen species formation, as well as lipid peroxidation and protein oxidation were described. At the same time, neither significant DNA oxidation nor reduction in glutathione levels was detected [38]. Based on the available data it can be concluded that CYN may be responsible for the oxidative stress and its consequences, but their range is varied and depends on the cell type.

The least studied toxin on its potential genotoxic activity is Antx-a. It has been detected that the toxin at a concentration of $0.5-2 \mu \mathrm{g} / \mathrm{ml}$ is able to induce the expression of the umuC gene, one of the SOS genes, in Salmonella typhimurium TA 1535 (pSK1002) [17]. Induction of the SOS genes is a way of bacterial responses to genotoxic damage. Further studies with the use of the Ames test with different bacterial strains did not confirm mutagenic potential of that toxin (unpublished data). There is no information on the Antx-a influence on genetic material of eukaryotic cells. In the present study we did not observe any DNA damage in the toxin-exposed fish cells. There was no increase in the apoptotic cell number, either, however in our previous studies, when longer exposure time was applied, the neurotoxin occurred to be able to activate caspases $3 / 7$ in carp cells. Additionally, alterations in phosphatidylserine location in cell membranes were seen at a toxin concentration of $1 \mu \mathrm{g} / \mathrm{ml}$, indicating dose-dependent proapoptotic activity of Antx-a [39].

In conclusion, MC-LR occurred to be the most toxic agent among the studied toxins toward carp leukocytes, exerting a proapoptotic and/or genotoxic influence. Some increase in DNA fragmentation was also detected after the cells treatment with CYN, not connected with the cell death. No effects of Antx-a on the treated cell under used in this study conditions were observed.

The authors declare no conflict of interest.

The study was financially supported by the National Center for Science, Grant No. N N304 306940.

\section{References}

1. Ferrão-Filho Ada S, Kozlowsky-Suzuki B (2011): Cyanotoxins: bioaccumulation and effects on aquatic animals. Mar Drugs 9: 2729-2772.

2. Stewart I, Seawright AA, Shaw GR (2008): Cyanobacterial poisoning in livestock, wild mammals and birds - an overview. Adv Exp Med Biol 619: 613-637.

3. Chorus I, Bartram J (1999): Toxic cyanobacteria in water: a guide to their public health consequences, monitoring and management. E\&FN Spon, London.

4. Žegura B, Straser A, Filipič M (2011): Genotoxicity and potential carcinogenicity of cyanobacterial toxins - a review. Mutat Res 727: 16-41.
5. Sierosławska A (2010): Immunotoxic, genotoxic and carcinogenic effects of cyanotoxins. Centr Eur J Immunol 35: 105-110.

6. Lankoff A, Carmichael W, Grasman KA, Yuan M (2004): The uptake kinetics and immunotoxic effects of microcystin-LR in human and chicken peripheral blood lymphocytes in vitro. Toxicology 204: 23-40.

7. Fischer A, Hoeger SJ, Stemmer K, Feurstein DJ, et al. (2010): The role of organic anion transporting polypeptides (OATPs/SLCOs) in the toxicity of different microcystin congeners in vitro: a comparison of primary human hepatocytes and OATP-transfected HEK293 cells. Toxicol Appl Pharmacol 245: 9-20.

8. Campos A, Vascolencos V (2010): Molecular mechanisms of microcystin toxicity in animal cells. Int J Mol Sci 11: 268-287

9. Bouaïcha N, Maatouk I, Plessis MJ, Périn F (2005): Genotoxic potential of Microcystin-LR and nodularin in vitro in primary cultured rat hepatocytes and in vivo in rat liver. Environ Toxicol 20: 341-347.

10. Zegura B, Sedmak B, Filipic M (2003): Microcystin-LR induces oxidative DNA damage in human hepatoma cell line HepG2. Toxicon 41: 41-48.

11. Lakshmana Rao PV, Bhattacharya R, Parida MM, et al. (1998): Freshwater cyanobacterium Microcystis aeruginosa (UTEX $2385)$ induced DNA damage in vivo and in vitro. Environ Toxicol Pharmacol 5: 1-6.

12. Lankoff A, Krzowski L, Glab J, Banasik A, et al. (2004): DNA damage and repair in human peripheral blood lymphocytes following treatment with microcystin-LR. Mutat Res/Genet Toxicol Environ Mutagen 559: 131-142.

13. Mankiewicz J, Walter Z, Tarczynska M, Palyvoda O, et al. (2002): Genotoxicity of cyanobacterial extracts containing microcystins from Polish water reservoirs as determined by SOS chromotest and comet assay. Environ Toxicol 17: 341-350.

14. Bain P, Burcham P, Falconer I, et al. (2010): Cylindrospermopsin mechanisms of toxicity and genotoxicity. Research Report No 61.

15. Humpage A, Fontaine F, Froscio S, et al. (2005): Cylindrospermopsin genotoxicity and cytotoxicity: role of cytochrome P-450 and oxidative stress. Toxicol Environ Health A 68: 739-753.

16. Žegura B, Gajski G, Štraser A, Garaj-Vrhovac V (2011): Cylindrospermopsin induced DNA damage and alteration in the expression of genes involved in the response to DNA damage, apoptosis and oxidative stress. Toxicon 58: 471-479.

17. Sieroslawska A, Rymuszka A (2010): Evaluation of genotoxic potential of neurotoxin anatoxin-a with the use of umuC test. NeuroEndocrinol Lett 31: 16-20.

18. da Silva RR, Pires OR Jr, Grisolia CK (2010): Toxicity and genotoxicity in Astyanax bimaculatus (Characidae) induced by microcystins from a bloom of Microcystis spp. Genet Mol Biol 33: 750-755.

19. Palíková M, Rábová M, Krejčí R, et al. (2007): Chromosomal aberrations in early embryos of weatherfish (Misgurnus fossilis $L$.) exposed to crude cyanobacterial extract and semipurified compound of microcystins - a pilot study. Acta Vet Brno 76: S55-S60.

20. Wu Q, Li M, Gao X, Giesy JP, et al. (2011): Genotoxicity of crude extracts of cyanobacteria from Taihu Lake on carp (Cyprinus carpio). Ecotoxicology 20: 1010-1017.

21. Rymuszka A (2012): Microcystin-LR induces cytotoxicity and affects carp immune cells by impairment of their phagocytosis and the organization of the cytoskeleton. J Appl Toxicol 2012. 
22. Ding WX, Shen HM, Zhu HG, et al. (1999): Genotoxicity of microcystic cyanobacteria extract of a water source in China. Mutat Res/Genet Toxicol Environ Mutagen 442: 69-77.

23. Maatouk N, Bouadcha I, Plessis MJ, Perin F (2004): Detection by 32P-postlabelling of 8-oxo-7 8-dihydro-2-0-deoxyguanosine in DNA as biomarker of microcystin-LR- and nodularin-induced DNA damage in vitro in primary cultured rat hepatocytes and in vivo in rat liver. Mutat Res/Genet Toxicol Environ Mutagen 564: 9-20.

24. Zegura B, Lah TT, Filipic M (2004): The role of reactive oxygen species in microcystin- LR-induced DNA damage. Toxicology 15: 59-68.

25. Zegura B, Volcic M, Lah TT, Filipic M (2008): Different sensitivities of human colon adenocarcinoma ( $\mathrm{CaCo}-2)$, astrocytoma (IPDDC-A2) and lymphoblastoid (NCNC) cell lines to microcystin-LR induced reactive oxygen species and DNA damage. Toxicon 52: 518-525.

26. Nong Q, Komatsu M, Izumo K, et al. (2007): Involvement of reactive oxygen species in Microcystin-LR-induced cytogenotoxicity. Free Radic Res 41: 1326-1337.

27. Bouaicha N, Maatouk I, Plessis MJ, Perin F (2005): Genotoxic potential of Microcystin-LR and nodularin in vitro in primary cultured rat hepatocytes and in vivo in rat liver. Environ Toxicol 20: 341-347.

28. Lankoff A, Bialczyk J, Dziga D, et al. (2006): Inhibition of nucleotide excision repair (NER) by microcystin-LR in CHOK1 cells. Toxicon 48: 957-965.

29. Olive P, Banath J (2006): The comet assay: a method to measure DNA damage in individual cells. Nat Protoc 1: 23-9.

30. Nagata S (2000): Apoptotic DNA fragmentation. Exp Cell Res 256: $12-18$.

31. Fadok VA, Savill JS, Haslett C, Bratton DL, et al. (1992): Different populations of macrophages use either the vitronectin receptor or the phosphatidylserine receptor to recognize and remove apoptotic cells. J Immunol 149: 4029-4035.

32. Collins JA, Schandi CA, Young KK, et al. (1997): Major DNA fragmentation is a late event in apoptosis. J Histochem Cytochem 45: 923-934.

33. Straser A, Filipic M, Zegura B (2011): Genotoxic effects of the cyanobacterial hepatotoxin cylindrospermopsin in the HepG2 cell line. Arch Toxicolo 85: 1617-1626.

34. Bazin E, Mourot A, Humpage AR, Fessard V (2010): Genotoxicity of a freshwater cyanotoxin, cylindrospermopsin, in two human cell lines: Caco-2 and HepaRG. Environ Mol Mutagen 51: 251-259.

35. Shen X, Lam PK, Shaw GR, Wickramasinghe W (2002): Genotoxicity investigation of a cyanobacterial toxin, cylindrospermopsin. Toxicon 40: 1499-1501.

36. Bazin E, Huet S, Jarry G, et al. (2012): Cytotoxic and genotoxic effects of cylindrospermopsin in mice treated by gavage or intraperitoneal injection. Environ Toxicol 27: 277-284.

37. Liebel S, Oliveira Ribeiro CA, Silva RC, et al. (2011): Cellular responses of Prochilodus lineatus hepatocytes after cylindrospermopsin exposure. Toxicol In Vitro 25: 1493-500.

38. Gutiérrez-Praena D, Jos A, Pichardo S, Cameán AM (2011): Oxidative stress responses in tilapia (Oreochromis niloticus) exposed to a single dose of pure cylindrospermopsin under laboratory conditions: influence of exposure route and time of sacrifice. Aquat Toxicol 105: 100-106

39. Rymuszka A, Sierosławska A (2010): Study on apoptotic effects of neurotoxin anatoxin-a on fish immune cells. Neuro Endocrinol Lett 31: 11-15. 